JAMP: Jurnal Adminitrasi dan Manajemen Pendidikan

Volume 5 Nomor 1 Maret 2022, Hal : 25 - 35

Tersedia Online di http://journal2.um.ac.id/index.php/jamp/

ISSN 2615-8574 (online)

JAMPP

JURNAL ADMINISTRASI DAN MANAJEMEN PENDIDIKAN

\title{
KUALITAS PEMBELAJARAN E-LEARNING BERDASARKAN PERSEPSI MAHASISWA
}

\author{
Desty Prawatiningsih, Nur Asia T \\ UIN Sultan Maulana Hasanuddin Banten - Jl. Jenderal Sudirman Serang, Banten \\ E-mail: desty.prawatiningsih@uinbanten.ac.id \\ Email :nur.asia@uinbanten.ac.id
}

\begin{abstract}
The goal of this research is to know the quality of the distance learning using by E-learning in pandemi Covid-19. The method of this research is study Survey by using Descriptive Quantitative Analysis. The research subjects were students of the Da'wah Faculty of UIN Sultan Maulana Hasanuddin Banten with a total sample of 314 respondents and data collection techniques with Non Probability Sampling with Accidental Sampling in the form of a questionnaire. The results of the study measure the quality of e-learning according to the student's perspective seen from: the level of quality of e-learning at the Da'wah Faculty in terms of quality: learning design, learning activities, delivery strategies, interaction between students and students and students with lecturers, learning assistance services, interaction students with teaching materials, collaboration, feedback systems, and learning assessments. The results of this study indicate that in general the quality of e-learning based on student perceptions includes good enough criteria.
\end{abstract}

\section{Keywords: E-Learning, Quality, Perception}

\begin{abstract}
Abstrak: Penelitian pembelajaran e-learning untuk mengetahui kualitas pembelajaran jarak jauh secara e-learning dalam kondisi pandemi covid-19. Metode penelitian adalah studi survei dengan teknik analisis data deskriptif. Subjek penelitian adalah mahasiswa fakultas Dakwah UIN Sultan Maulana Hasanuddin Banten dengan jumlah sampel sebanyak 314 responden dan teknik pengumpulan data dengan Non Probability Sampling jenis Accidental Sampling dalam bentuk kuesioner. Penelitian ini mengukur kualitas e-learning menurut perspektif mahasiswa dilihat dari tingkat kualitas pembelajaran e-learning yaitu kualitas rancangan pembelajaran, kegiatan pembelajaran, strategi penyampaian, interaksi antar mahasiswa dengan mahasiswa dan mahasiswa dengan dosen, layanan bantuan pembelajaran, interaksi mahasiswa dengan bahan ajar, kolaborasi, sistem umpan balik, serta penilaian pembelajaran. Hasil penelitian ini menunjukkan secara umum mutu pembelajaran e-learning berdasarkan persepsi mahasiswa termasuk kriteria cukup baik.
\end{abstract}

Kata kunci: E-Learning, Kualitas, Persepsi

pandemi Covid-19 menyebabkan dunia pendidikan khususnya perguruan tinggi harus mengubah kegiatan pembelajaran secara langsung menjadi pembelajaran jarak jauh melalui metode e-learning. Kegiatan Pembelajaran adalah kegiatan yang penting bagi mahasiswa dalam proses pencapaian ilmu pengetahuan dan wawasan. Penelitian terdahulu yang dilaksanakan dengan mewawancarai mahasiswa sebanyak 65\% mahasiswa menyukai pembelajaran jarak jauh menggunakan metode e- learning dan yang tidak suka sebesar 35\% (Zuraini and Nurhayati, 2021). Oleh karenanya pembelajaran secara daring adalah solusi dalam kegiatan belajar mengajar dimasa pandemi ini.

Peraturan Pemerintah Nomor 19 tentang Standar Nasional Pendidikan Tahun 2005 menjelaskan bahwa penyelenggaraan pembelajaran harus interaktif, inspiratif, menarik, menantang, menginspirasi peserta didik untuk berpartisipasi aktif, dan dapat berbasis perkembangan dan psikologi peserta didik 
memberikan kesempatan berdiskusi, yang mana sangat membantu untuk menumbuhkan pemikiran kritis siswa (Sitepu and Lestari, 2018).

Pembelajaran e-learning adalah pembelajaran penggunaan jaringan internet yang bisa diikuti secara gratis atau dengan biaya tertentu (Baety and Munandar, 2021). Perkembangan pembelajaran dengan teknologi internet memberi kemudahan dan keleluasaan untuk mengembangkan ilmu pengetahuan secara digital. Model Pembelajaran yang ditekankan pada aktivitas modernisasi atas bantuan teknologi, diharapkan membantu mahasiswa untuk lebih mudah dalam memahami materi perkuliahan secara interaktif, produktif, efektif, inspiratif dan konstruktif. Mahasiswa juga diharapkan memiliki keterampilan dari penggunaan teknologi tersebut. Pemanfaatan internet mempermudah mahasiswa dalam mencari berbagai literatur dan referensi pengetahuan secara cepat, sehingga proses belajar mengajar menjadi lebih efektif dan efisien. Metode pembelajaran ini biasanya disebut dengan metode pembelajaran electronic learning (Bora, 2017).

Pembelajaran model e-learning yang dilakukan saat ini merupakan bagian dari standar proses pembelajaran jarak jauh yang seharusnya selalu dilakukan perbaikan dan peningkatan yang berkelanjutan melalui siklus PPEPP (Penetapan, Pelaksanaan, Evaluasi, Pengendalian, dan Peningkatan), sehingga dapat dievaluasi, dikendalikan dan ditingkatkan. Efektifitas Pemanfaatan pembelajaran secara online dengan mengubah metode penbelajaran dari tekstual menjadi kontekstual dimana mahasiswa harus mampu untuk lebih memahami pengetahuan dikaitkan dengan kehidupan nyata.

Pembelajaran oleh dosen adalah pelayanan yang dilakukan dosen sebagai amanat kepada mahasiswa, Pelayanan tersebut harus memperhatikan kualitas/mutu. Konsep kualitas/Mutu lahir dari dunia industri yang merupakan pintu masuk perbaikan mutu pendidikan yang mengacu pada input, proses, output dan dampak (Baharun and Zamroni, 2017). Mutu pelayanan pendidikan didefinisikan sebagai kegiatan yang dilakukan oleh pemberi jasa (Dosen). Jika mutu pelayanan dosen sebagai pemberi jasa dapat melebihi dari nilai harapan mahasiswa sebagai penerima jasa maka akan ada kepuasan dari penerima jasa, sementara itu kepuasan didefiniskan sebagai perasaan senang yang hadir setelah membandingkan kinerja dan nilai harapan dari proses pelaksanaan kegiatan (Aqib and Khoiriyah, 2020). Sistem pembelajaran e-learning yang memanfaatkan teknologi informasi dan komunikasi adalah alternatif yang paling memungkinkan dalam kondisi saat ini yang mengaruskan setiap orang untuk menjaga jarak demi mencegah penyebaran virus covid-19 dan mematuhi aturan pemerintah untuk tidak berkumpul di satu tempat.

Hasil penelitian yang dilakukan oleh Baety et al. (2021) menjelaskan bahwa media e-learning yang paling banyak digunakan adalah Google Classroom dengan rasio 72,9\%, group chat (WA/line) sebesar $62,7 \%$, zoom meeting sebesar $35,6 \%$, youtube $29,7 \%$, edmodo $18,6 \%$. Google Classroom adalah platform paling populer di antara model pembelajaran e-learning karena fungsi aplikasinya yang efisien dan mudah digunakan (Baety and Munandar, 2021).

Pembelajaran dinyatakan efektif jika dikaji dari indikator kulaitas pembelajaran yang menjadi standar pembelajaran perguruan tinggi. Minat dan motivasi mahasiswa tertumpu pada aspek kewajiban mereka untuk mengikuti perkuliahan agar mendapatkan tambahan wawasan dari kegiatan pembelajaran tersebut. Pembelajaran oleh tenaga pendidik (dosen) adalah pelayanan yang diberikan kepada konsumen (mahasiswa) sehingga dalam memberikan pelayanan tentu guna memperhatikan aspek kualitas layanan itu sendiri. Ketika kualitas/mutu pelayanan melebihi dari harapan maka akan timbul rasa puas (Aqib and Khoiriyah, 2020). Untuk menilai seberapa baik kegiatan pembelajaran secara e-learning, salah satu tolak ukurnya menganalisa kualitas pembelajaran e-learning berdasarkan perspektif mahasiswa. Penelitian ini diharapkan kedepannya akan ada peningkatan kualitas pembelajaran e-learning sehingga dapat menghasilkan mahasiswa/alumni yang berkualitas.

\section{METODE}

Penelitian ini menggunakan pendekatan survey, dimana pendekatan ini digunakan untuk memecahkan masalah yang terjadi secara faktual dengan menggunakan sampel tertentu (Hamdani and Priatna, 2020). Objek yang diteliti adalah proses pembelajaran jarak jauh dengan model pembelajaran 
e-learning. Waktu penelitian dilaksanakan selama lima bulan yaitu Februari s.d Juni 2021 di Fakultas Dakwah UIN Sultan Maulanan Hasanuddin Banten.

Subjek penelitian adalah mahasiswa Fakultas Dakwah UIN Sultan Maulana Hasanuddin Banten. Instrumen yang digunakan yaitu kuesioner melalui google form. Instrumen diuji validitas dan reliabilitas agar dapat memberikan hasil yang dapat dipercaya dan data yang dapat dipertanggungjawabkan. Penelitian ini menggunakan data primer dan sekunder. Data primer adalah data yang diperoleh dari pengisian kuesioner oleh mahasiswa (setiap mahasiswa hanya memiliki hak untuk mengisi satu form kuesioner). Sementara itu, observasi digunakan sebagai data sekunder untuk memperkuat data primer. Responden yang diambil sebagai sample adalah 314 responden dengan jumlah populasi 1600 orang. Teknik analisis data menggunakan teknik analisis deskriptif yang selanjutnya Analasis data yang digunakan yaitu analisis deskriptif dengan formula stanfive yang dituangkan dalam bentuk table distribusi frekuensi.

\section{HASIL DAN PEMBAHASAN}

Pembelajaran e-learning dimasa pandemi covid-19 cukup efektif untuk memenuhi tuntutan dalam penyampaian ilmu pengetahuan. Akan tetapi pada kenyataannya ketidaksiapan pendidik (dosen) dan peserta didik (mahasiswa) dalam menghadapi pembelajaran e-learning menjadi salah satu permasalahan yang sudah umum. Dalam situasi ini, pembelajaran dengan metode e-learning tetap harus dilaksanakan agar proses pembelajaran dapat tetap terlaksana. Pembelajaran dilaksanakan dengan model pembelajaran sinkronus dan asinkronus, disesuaikan dengan kebutuhan dari setiap matakuliah yang diajarkan. Dalam menentukan pelaksanaan pembelaajran secara online apakah telah memenuhi indikator yang disesuaikan dengan ketetapan SN Dikti, Permendikbud No 3 Tahun 2020 serta PMA Direktorat Jendral Pendidikan Islam maka disesuaikan dan diturunkan menjadi indikator yang digunakan. Adapun indikator yang digunakan pada penelitian ini adalah:

Tabel 1. Indikator Kualitas Pembelajaran

\begin{tabular}{llc}
\hline No & \multicolumn{1}{c}{ Indikator } & $\begin{array}{c}\text { Jumlah Pertanyaan } \\
\text { Kuesioner }\end{array}$ \\
\hline 1 & Rancangan Pembelajaran & 12 \\
2 & Kegiatan Pembelajaran & 3 \\
3 & Strategi Penyampaian & 4 \\
4 & Interaksi Antar Mahasiswa dan Mahasiswa dengan Dosen & 3 \\
5 & Interaksi Mahasiswa dengan Bahan Ajar & 5 \\
6 & Mutu Kolaborasi & 4 \\
7 & Sistem Umpan Balik & 3 \\
8 & Penilaian Pembelajaran & 3 \\
9 & Layanan Bantuan Pembelajaran & 5 \\
\hline
\end{tabular}

Hasil tabulasi data kuesioner di analisis dengan formula stanfive yaitu persepsi mahasiswa terhadap mutu pembelajaran e-learning dan secara umum disajikan dalam bentuk diagram dibawah dengan peroleh persentase yaitu cukup baik $50 \%$, kurang baik $28 \%$, Baik $11 \%$, tidak baik $6 \%$ dan sangat baik $5 \%$, dapat dilihat pada Gambar1. Persepsi Mahasiswa Terhadap Kualitas Pembelajaran E-Learning. 


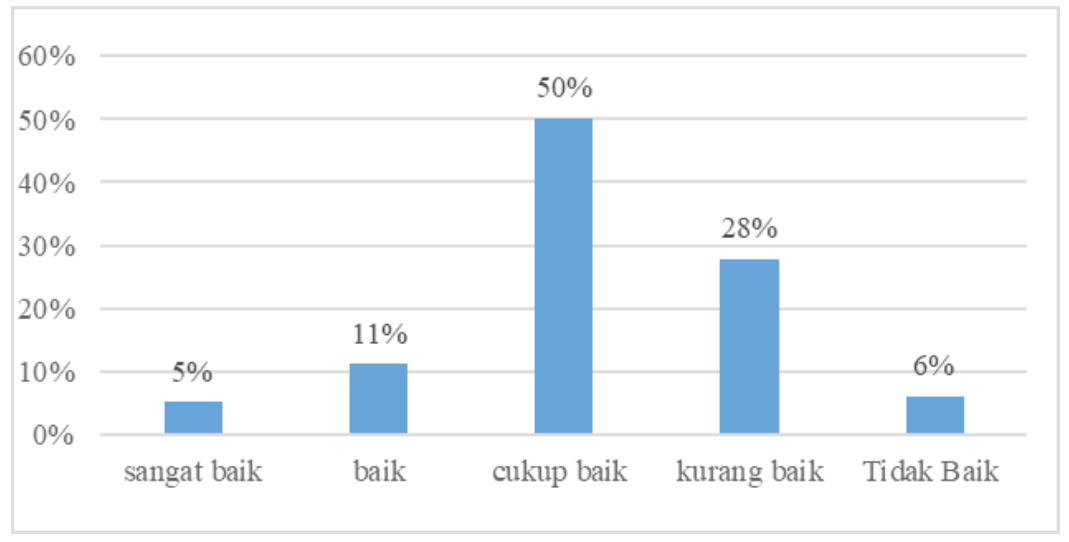

Gambar 1. Persepsi Mahasiswa Terhadap Kualitas Pembelajaran E-Learning

\section{Kualitas Rancangan Pembelajaran}

Hasil analisis kuesioner menunjukkan 36,31\% menilai kualitas rancangan pembelajaran dengan metode e-learning cukup baik, 30,25\% responden menilai mutu rancangan pembelajaran baik, 23,25\% kurang baik, 6,05\% sangat baik dan sisanya 4,14\% merasa mutu rancangan pembelajaran tidak baik (Lihat Gambar 2. Persepsi Mahasiswa terhadap Kualitas Rancangan Pembelajaran ).

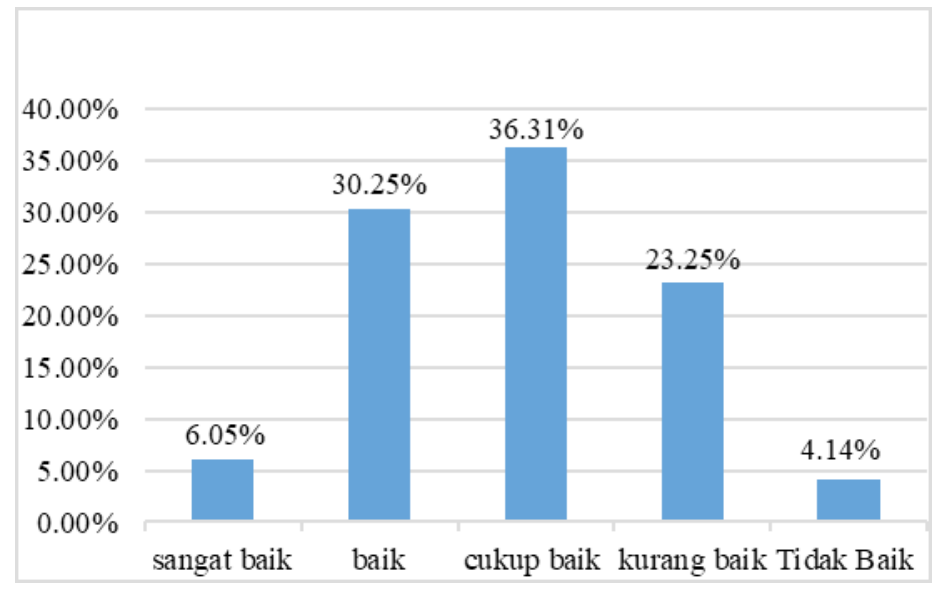

Gambar 2. Persepsi Mahasiswa terhadap Kualitas Rancangan Pembelajaran

Rancangan Pembelajaran yang bermutu mencantumkan informasi-informasi penting mengenai bahan perkuliahan untuk mencapai tujuan perkuliahan. Rancangan pembelajaran yang biasa disebut dengan RPS juga mencakup kontrak perkuliahan, deskripsi matakuliah, tujuan dan pokok bahasan, strategi pembelajaran dalam perkuliahan, model penilaian serta referensi yang digunakan dalam pembelajaran matakuliah tersebut (Sitepu and Lestari, 2018).

Rancangan Pembelajaran e-learning seharusnya memuat kompetensi, deskripsi matakuliah, bobot sks, dosen pengampu matakuliah, topik materi, pengalaman pembelajaran, media pembelajaran, sumber referensi serta kriteria evaluasi yang digunakan. Salah satu kriteria penilaian kualitas Rancangan Pembelajaran adalah ketepatan waktu dosen dalam penyampaian Rancnagan Pembelajaran, penjelasan dosen tentang Rancangan Pembelajaran, dosen menjelaskan tujuan permbelajaran sehingga mahasiswa memahami isi dari Rancangan Pembelajaran serta dosen menerima masukan dari mahasiswa dalam penyempurnaan Rancangan Pembelajaran.

Menurut Pramuniati (Pramuniati et al., 2020) rancangan pembelajaran yang baik sekurangkurangnya memuat: Nama program studi, nama dan kode mata kuliah, semester, sks, nama dosen pengampu, capaian pembelajaran lulusan yang dibebankan pada mata kuliah; Kemampuan akhir yang direncanakan untuk memenuhi capaian pembelajaran lulusan; Materi sesuai dengan target kemampuan 
yang akan dicapai; Metode pembelajaran; Waktu yang disediakan untuk mencapai target pembelajaran pada tiap tahap pembelajaran; Pengalaman belajar mahasiswa yang dituangkan dalam deskripsi tugas yang harus dikerjakan oleh mahasiswa selama satu semester; Kriteria, indikator, dan bobot penilaian; Daftar rujukan yang digunakan

Dalam Proses pelaksanaan perkuliahan seharusnya dosen mengacu pada rencana pembelajaran yang telah tetapkan agar pembelajaran berjalan secara sistematis dan efektif. Selain itu juga, pokok bahasan yang disampaikan dosen dalam perkuliahan harus sesuai dengan RPS agar mahasiswa mempersiapkan diri sebelum dimulainya perkuliahan. Kejelasan sumber referensi/bahan rujukan perkuliahan dituangkan dengan jelas dalam RPS yang memudahkan mahasiswa dalam mencari bahan pembelajaran mata kuliah.

\section{Kualitas Kegiatan Pembelajaran}

Hasil analisis kuesioner untuk kualitas kegiatan pembelajaran e-learning menurut persepsi mahasiswa mendapatkan persentase baik sebesar 37\%, cukup baik 33\%, kurang baik 18\%, sangat baik $8 \%$ dan $4 \%$ menyatakan tidak baik (lihat gambar 3. Persepsi Mahasiswa terhadap Kualitas Kegiatan Pembelajaran). Pembelajaran e-learning merupakan pembelajaran berbasis internet bisa melalui beberapa aplikasi yang tersedia saat ini yaitu Zoom Meeting, Google Classroom, Google Meet, Edmodo, Microsoft Team atau Whatsapp group.

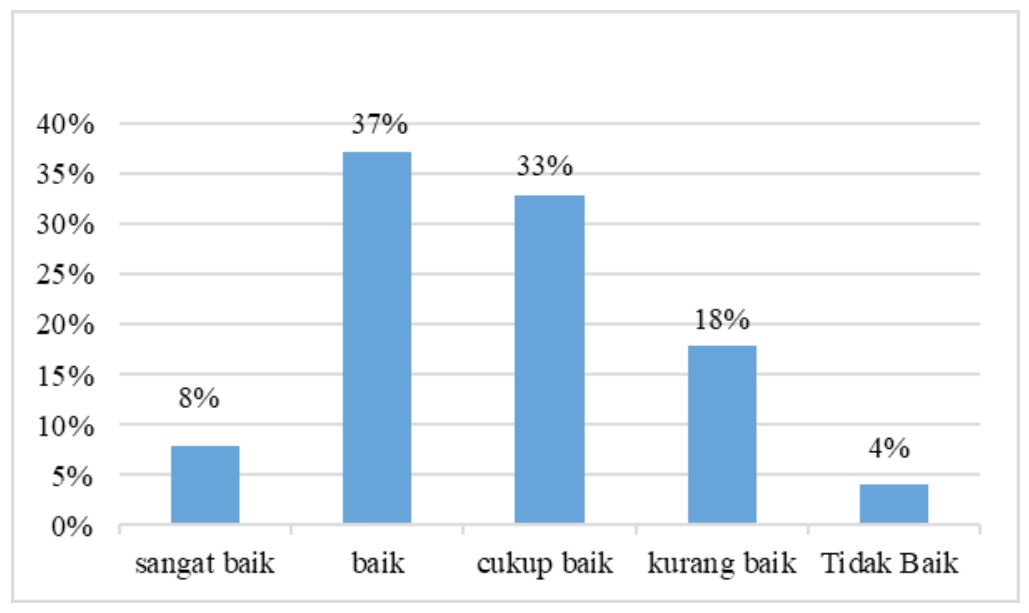

Gambar 3. Persepsi Mahasiswa terhadap Kualitas Kegiatan Pembelajaran

Selain itu juga dibutuhkan koneksi internet yang stabil agar pembelajaran dapat berlangsung tanpa hambatan. Kesulitan dalam memantau perkembangan pembelajaran dapat disebabkan karena sulitnya mengakses informasi dan terbatasnya ketersediaan koneksi internet (Napitupulu, 2020). Proses pembelajaran memiliki dua ciri utama, yaitu: Proses pembelajaran yang melibatkan proses psikologis siswa secara maksimal tidak hanya menuntut siswa hanya mendengarkan dan mencatat, tetapi juga menuntut siswa untuk melakukan aktivitas dalam proses berpikir. Kedua, proses pembelajaran dibangun dalam suasana dialog dan proses tanya jawab yang terus menerus untuk meningkatkan dan meningkatkan kemampuan berpikir siswa, dan kemudian membantu mereka memperoleh pengetahuan yang telah mereka konstruksikan (Subhi, 2020).

Hasil analisis kuesioner $45 \%$ responden merasa bahwa kualitas kegiatan pembelajaran sudah baik dan 51\% merasa cukup baik. Banyak hal yang mempengaruhi penilaian kualitas pembelajaran diantaranya adalah dosen memberikan kesempatan kepada mahasiswa sehingga dapat mengikuti pembelajaran secara mandiri, aktif dan bertanggungjawab serta tujuan dari kegiatan pembelajaran yang sudah direncanakan dapat tercapai. Selain itu juga, proses pembelajaran diupayakan memberi pengalaman belajar yang otentik dan bermakna sehingga membantu mahasiswa menerapkan ilmu yang diperoleh selama proses pembelajaran dan mencapai tujuan yang dicita-citaka. Menurut Pramuniati (Pramuniati et al., 2020) kegiatan pembelajaran e-learning seharusnya memperhatikan beberapa hal yaitu; Desain Pembelajaran e-learning membuat mahasiswa terlibat dalam pembelajaran aktif; Metode pembelajaran e-learning memberikan pengalaman belajar yang apa adanya dan bermakna sehingga membantu mahasiswa 
menerapkan konsep ilmu serta mencapai tujuan pembelajarannya; Strategi Pembelajaran e-learning harus yang mempertimbangkan berbagai gaya belajar mahasiswa; Menumbuhkan jiwa 'e-komunitas' diantara mahasiswa.

\section{Kualitas Strategi Penyampaian}

Dalam merumuskan indikator Kualitas stategi penyampai yang dirumuskan dari beberapa sub indikator yaitu: 1) Dosen menerapkan prinsip pengajaran yang berpusat pada mahasiswa, 2) Dosen membiarkan mahasiswa berpartisipasi aktif dalam proses pembelajaran, 3) Dosen memberikan bimbingan yang jelas dan rinci, 4) Dosen memberikan materi pembelajaran berupa informasi teks, grafik, dan gambar ( gambar), Audio, video, simulasi, animasi, glosarium, forum, dll, dan dapat diakses lintas ruang dan waktu melalui LMS (Learning Management System).

Hasil tabulasi data kuesioner untuk mutu strategi penyampaian materi pada pembelajaran e-learning, berdasarkan perspektif mahasiswa mendapatkan presentasi baik sebesar $40 \%$, kurang baik sebesar $24 \%$, cukup baik sebesar 23\%, sangat baik 9\% dan tidak baik sebesar 4\%. Dapat diamati pada Gambar 4 . Persepsi Mahasiswa terhadap Kualitas strategi penyampaian.

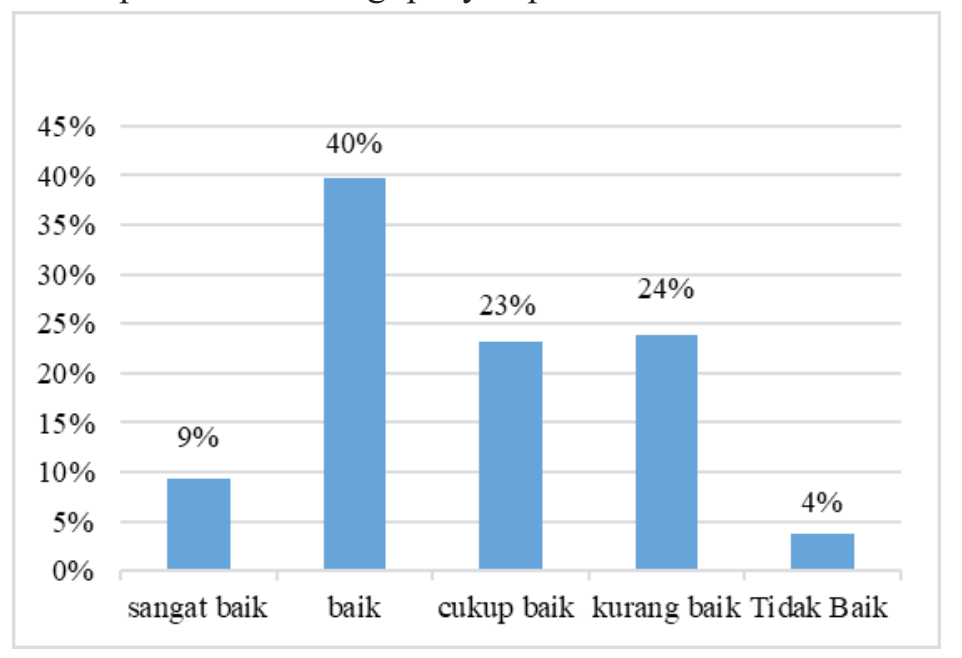

Gambar 4. Persepsi Mahasiswa terhadap Kualitas Strategi Penyampaian

Tantangan yang dihadapi pendidik untuk menjaga kualitas kegiatan pembelajaran e-learning adalah proses penyampaian materi agar mudah dipahami oleh mahasiswa. Dosen perlu mengembangkan pembelajaran melalui kombinasi e-learning dengan model pembelajaran dan bahan ajar yang sesuai dengan karakteristik materi, sehingga penggunaan e-learning lebih maksimal serta dapat memberikan bekal kepada mahasiswa di era digital ini (Saifuddin, 2018). Menurut Pramuniati (Pramuniati et al., 2020) strategi pendidik untuk penyampaian materi dalam pembelajaran e-learning yang dapat dilakukan adalah : Pengajaran yang berpusat pada mahasiswa; Mahasiswa dilibatkan dalam proses penyampaian materi pemberlajan sehingga aktif dalam proses belajar; Pembelajaran e-learnng disetiap proses pembelajaran dengan instruksi yang jelas dan terperinci.

\section{Kualitas Interaksi Mahasiswa dengan Bahan Ajar}

Aspek yang menjadi penilaian dasar dala merumuskan Kualitas interaksi antara siswa dan bahan pembelajaran adalah: 1) Sistem yang digunakan memungkinkan penyajian bahan dalam berbagai cara; pertemuan online, chatting, dll, 2) Sistem yang diterapkan memberikan kesempatan kepada siswa untuk mempelajari materi secara mandiri sesuai dengan kemampuannya, 3) Sistem yang diterapkan memberikan kesempatan kepada siswa untuk mengevaluasi diri secara mandiri untuk memahami hasil belajarnya, 4) Adanya sistem yang diterapkan dapat memberikan informasi kepada dosen dan mahasiswa tentang kemajuan dan hasil belajar, 5) Skenario kegiatan pembelajaran, jalur pembelajaran, media pembelajaran, evaluasi hasil belajar, dan aspek umpan balik yang dirancang secara terintegrasi. 
Mutu interaksi mahasiswa dengan bahan ajar menurut persepsi mahasiswa di jelaskan pada gambar 5 Persepsi Mahasiswa terhadap KUalitas Interaksi Mahasiswa dengan Bahan Ajar, Dengan persentase baik sebesar $8 \%$, cukup baik sebesar $28 \%$, kurang baik $23 \%$, sangat baik $8 \%$ dan tidak baik $4 \%$.

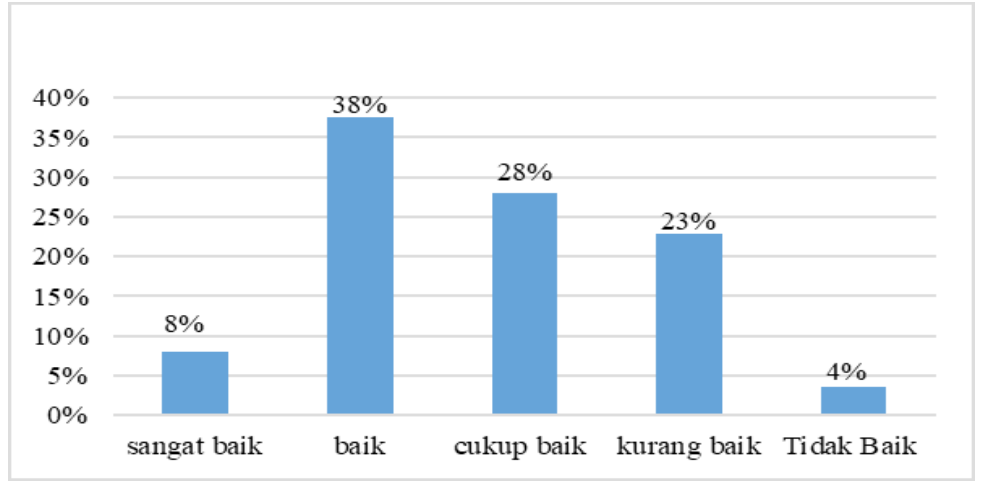

Gambar 5. Persepsi Mahasiswa terhadap Kualitas Interaksi Mahasiswa dengan Bahan Ajar

Dalam proses pembelajaran seharusnya mahasiswa dapat berinteraksi dengan bahan ajar secara optimal. Hal ini sejalan dengan hasil penelitian terdahulu dimana mayoritas mahasiswa merasa tidak puas terhadap pembelajaran jarak jauh alasannya adalah mahasiswa selama ini sudah terbiasa dengan menerima pembelajaran tatap muka, sehingga mungkin adanya ketidaksiapan dalam menggunakan metode pembelajaran e-learning (Napitupulu, 2020).

Delone \& McLean (2003) menyatakan mutu pembelajaran e-learning haruslah berfokus pada karakteristik kinerja sistem yaitu kemudahan penggunaan, kemudahan dipelajari user/ pengguna, kecepatan akses, keandalan sistem, fleksibilitas, kegunaan fitur dan fungsi sistem, serta keamanan(Handayani and Wiyata, 2020). Menurut Pramuniati peningkatan mutu interaksi mahasiswa dengan bahan ajar sebaiknya dilaksanakan dengan cara: Bahan ajar disajikan secara digital melalui berbagai cara yaitu video konferensi, percakapan online (chat) atau e-mail; Mahasiswa diberikan kesempatan untuk mempelajari materi secara mandiri sesuai dengan kemampuannya; Mahasiswa diberi kesempatan untuk mengevaluasi diri secara mandiri guna mengukur seberapa besar capaian belajarnya; Mahasiswa diberi kemudahan dalam mengakses tutorial online dan semua layanan yang mendukung pembelajaran e-learning kapanpun dan dimanapun mereka berada; Adanya sistem/ perangkat yang dapat memberikan informasi pada dosen dan mahasiswa tentang kemajuan dan capaian belajar yang di dapat.

\section{Kualitas Layanan Bantuan Pembelajaran}

Diagram dibawah ini menunjukkan mutu layanan bantuan pembelajaran dimana $43 \%$ mahasiswa memberikan nilai cukup baik, $31 \%$ baik, $14 \%$ kurang baik, $6 \%$ sangat baik dan $6 \%$ tidak baik.

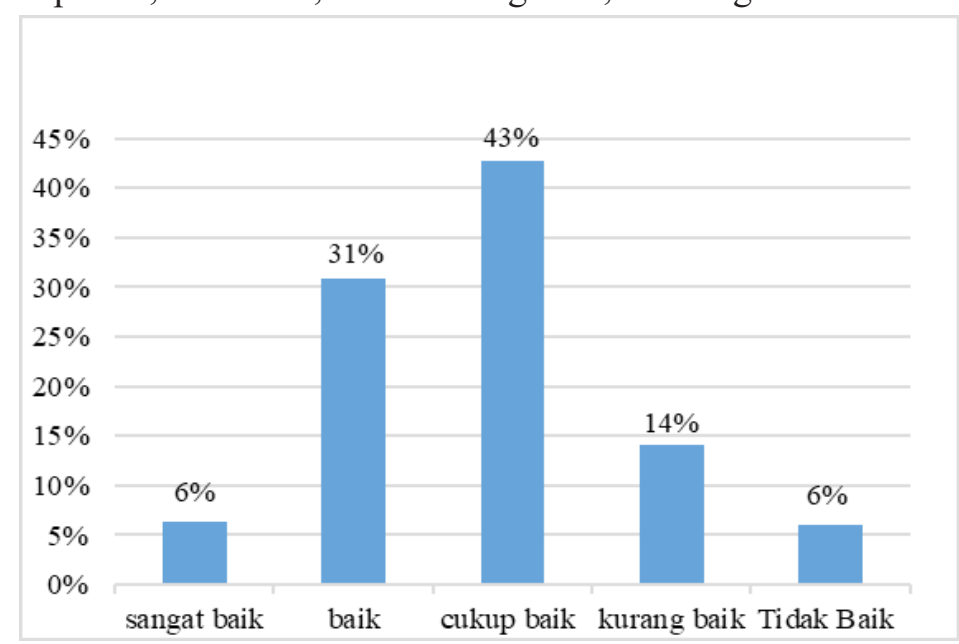

Gambar 6. Persepsi Mahasiswa terhadap Kualitas Layanan Bantuan Pembelajaran 
E-learning membantu mahasiswa dalam mempelajari materi secara mandiri sebelum kelas dimulai, sehingga dapat meningkatkan motivasi mahasiswa dalam proses pembelajaran di dalam kelas (Saifuddin, 2018). Menurut Pramuniati (Pramuniati et al., 2020) layanan bantuan pembelajaran e-learning yang seharusnya ditingkatkan agar mahasiswa menjadi lebih maksimal dalam mengikuti pembelajaran e-learning adalah : Tersedianya sistem layanan informasi akademik, sistem administrasi akademik, serta sistem bantuan teknis (TIK), yang seharusnya mudah diakses oleh mahasiswa dimanapun dan kapan, sehingga tidak menghambat proses belajar mahasiswa; Adanya program pelatihan/sosialisasi secara online/tatap muka terhadap mahasiswa agar mahir dan memiliki keterampilan belajar jarak jauh/ belajar mandiri (study \& technical skills); Menyediakan sistem layanan konseling online, sistem pembimbingan akademik online, dan sistem pelayanan pengembangan karir secara online.; Mahasiswa dapat mengakses terhadap berbagai sumber belajar (e-resources) online dalam bentuk perpustakaan digital atau repository; Tersedianya sistem informasi kemajuan belajar mahasiswa serta tersedia sistem wadah pengaduan mahasiswa secara daring.

\section{Kualitas Interaksi Antar Mahasiswa dan Mahasiswa serta Mahasiswa dengan Dosen}

Kualitas Interaksi Mahasiswa dan Mahasiswa serta dosen dirumuskan berdasarkan beberapa aspek yaitu: 1) Teknologi komunikasi yang digunakan memungkinkan mahasiswa untuk saling berbicara antara mahasiswa dan dosen, 2) Teknologi komunikasi yang digunakan memungkinkan mahasiswa untuk mengirimkan tugas secara elektronik, 3) Teknologi komunikasi yang digunakan memungkinkan dosen berinteraksi dengan seluruh mahasiswa

Kualitas/mutu interaksi mahasiswa dengan mahasiswa, serta mahasiswa dengan dosen digambar pada Gambar 7 persepsi Mahasiswa terhadap Kualitas Interaksi Antara Mahasiswa serta Mahasiswa dengan Dosen mendapatkan persentase baik sebesar 38\%, cukup baik sebesar 27\%, kurang baik sebesar $20 \%$, sangat baik $13 \%$ dan tidak baik sebesar $2 \%$.

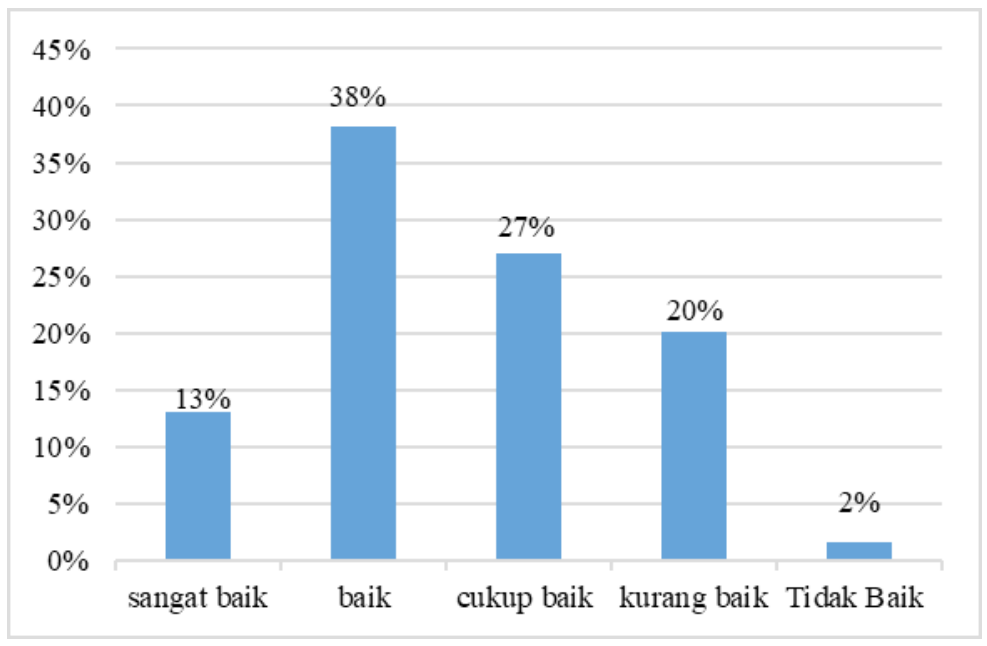

Gambar 7. Persepsi Mahasiswa terhadap Kualitas Interaksi Antara Mahasiswa serta Mahasiswa dengan Dosen

Peningkatan kualitas interaksi antar mahasiswa dan dosen secara e-learning dengan mengembangkan teknologi komunikasi digital yang menunjang kegiatan: Tersedianya sistem yang menunjang komunikasi dan interaksi antar Mahasiswa dan dosen baik secara berkelompok ataupun individu; Tersedianya sistem yang menyediakan layanan pengiriman tugas secara elektronik dari Mahasiswa; Tersedianya wadah komunikasi online antara dosen dan mahasiswa secara sinkronus dan asinkronus; Tersedianya beberapa alternatif pilihan sistem komunikasi digital sehingga dosen dapat memilih saluran pembelajaran e-learning yang tepat untuk setiap kegiatan yang disesuaikan dengan kebutuhan.

\section{Kualitas Kolaborasi}

Kualitas Kolaborasi dirumuskan berdasarkan beberapa aspek yaitu: 1) sistem yang digunakan memungkinkan siswa untuk mengadakan kegiatan kolaboratif, 2) Pencapaian atau tujuan dan kegiatan kolaboratif didefinisikan dengan jelas, 3) bukti sistem penilaian untuk kegiatan kolaboratif, baik per kelompok maupun per individu, dijelaskan dengan jelas. 
Kualitas Kolaborasi menurut persepsi mahasiswa dapat dilihat pada Gambar 8. Persepsi Mahasiswa terhadap Kualitas Kolaborasi. Pada gambar dijelaskan bahwa Mutu Kolaborasi dalam pembelajaran menurut persepsi mahasiswa mendapatkan persentase baik sebesar 33\%, cukup baik 33\%, kurang baik sebesar $21 \%$, snagat baik $7 \%$ dan tidak baik $6 \%$.

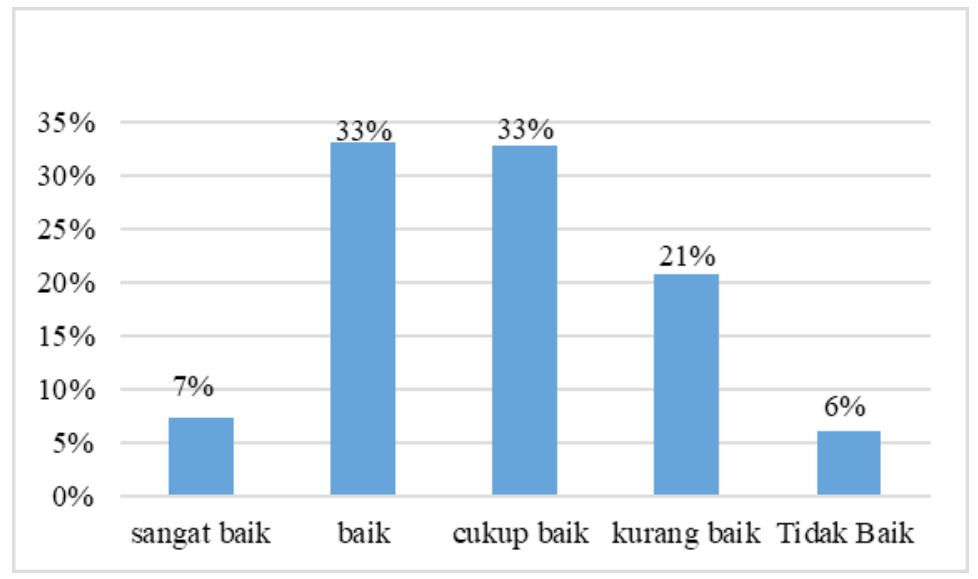

Gambar 8. Persepsi Mahasiswa terhadap Kualitas Kolaborasi

Sistem kolaborasi yang baik menurut Pramuniati (Pramuniati et al., 2020) seharusnya memperhatikan beberapa hal dibawah ini : Mendukung mahasiswa untuk melakukan kegiatan kolaborati baik dengan dosen ataupun dengan mahasiswa lainnya; Pencapaian tujuan dan kegiatan kolaboratif didefinisikan secara jelas dalam standar operasional prosedur atau peraturan lainnya; Setiap manfaat kegiatan kolaboratif bagi dituliskan dengan jelas; Sistem penilaian yang jelas untuk setiap kegiatan kolaboratif, baik per kelompok maupun per individu.

\section{Kualitas Sistem Umpan Balik}

Kualitas sistem umpan balik dirumuskan berdasarkan beberapa aspek yaitu : 1) Jadwal tugas, ujian, dan umpan balik dicantumkan dalam pertemuan awal, 2) Pemberian penjelasan tentang tugas-tugas yang diberikan dan hasil yang diharapkan dicantumkan di pertemuan awal 3) Umpan balik diberikan dengan baik oleh dosen dan rekan sejawat siswa. Kualitas sistem umpan balik pembelajaran menurut persepsi mahasiswa mendapatkan persentase baik sebesar $42 \%$, cukup baik sebesar $25 \%$, kurang baik $21 \%$, sangat baik $11 \%$ dan tidak baik 2\%. (Lihat Gambar 9. Persepsi Mahasiswa terhadap Kualitas Sistem Umpan Balik).

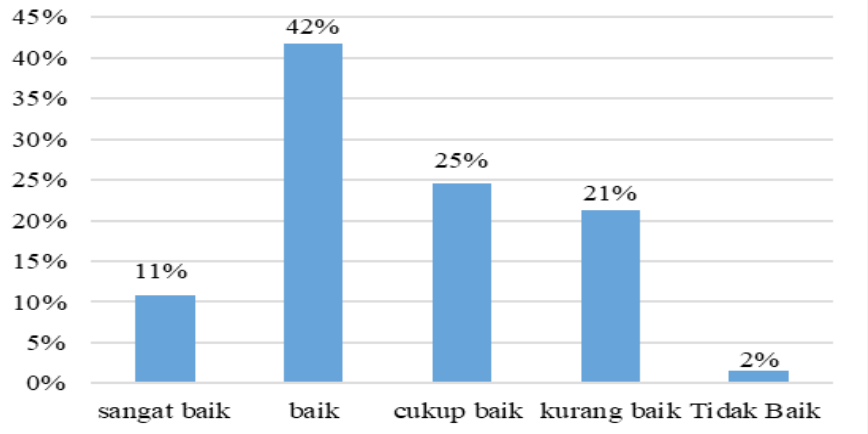

Gambar 9. Persepsi Mahasiswa terhadap Kualitas Sistem Umpan Balik

Prosedur dalam menjaga mutu umpan balik yang sebaiknya dilaksanakan dalam proses pembelajaran e-learning adalah: Umpan balik dijelaskan diawal pembelajaran yaitu mencakup jadwal tugas, ujian dan umpan balik; Tugas-tugas yang diberikan dan hasil yang diharapkan dicantumkan dalam RPS dan dijelaskan diawal pembelajaran; Adanya umpan balik baik oleh dosen maupun oleh mahasiswa untuk kemajuan pembelajaran. 


\section{Kualitas Penilaian Pembelajaran}

Kualitas penilaian pembelajaran disusun berdasarkan beberapa aspek yaitu: 1) Sistem penilaian dituliskan dan diinformasikan dengan jelas dan dapat diakses oleh mahasiswa, 2)Kompetensi atau capaian belajar dituliskan dengan jelas pada setiap awal kegiatan pembelajaran, 3) Penilaian diberikan dalam beberapa tahapan selama proses belajar; penugasan, Ujian Tengah Semester (UTS) dan Ujian Akhir Semester (UAS).

Kualitas penilaian pembelajaran menurut persepsi mahasiswa mendapatkan persentase baik sebesar $49 \%$, cukup baik sebesar 21\%, kurang baik 18\%, sangat baik 10\% dan tidak baik $1 \%$. (Lihat Gambar 10 . Persepsi Mahasiswa terhadap kualitas Penilaian Pembelajaran)

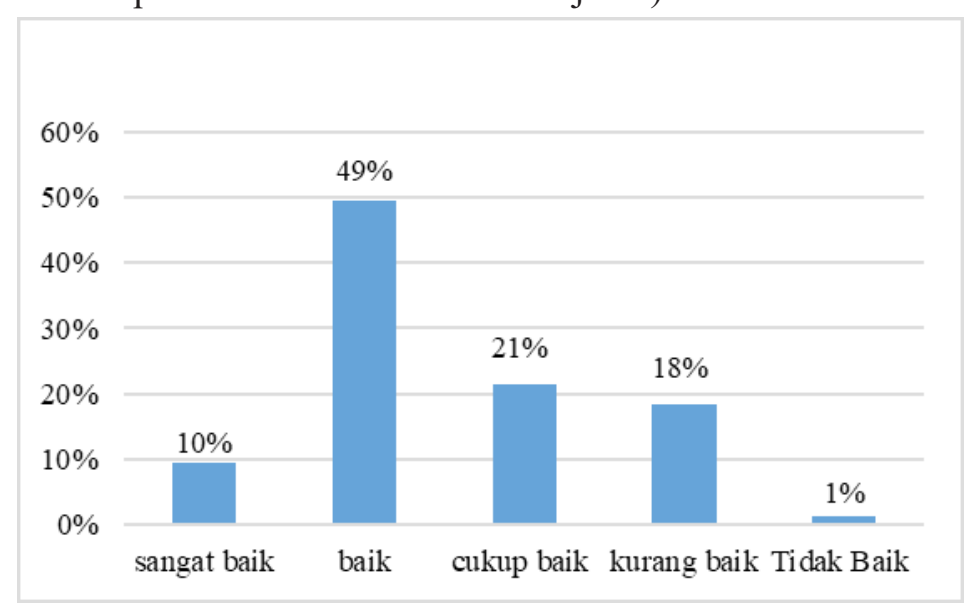

Gambar 10. Persepsi Mahasiswa terhadap Kualitas Penilaian Pembelajaran

Untuk menjaga kualitas dalam sistem penilaian pembelajaran, sebaiknya prosedur yang dilakukan dengan memperhatikan: Sistem penilaian dituliskan dengan jelas dalam RPS; Kompetensi dan capaian belajar di tuliskan dalam RPS dan dijelaskan diawal pembelajaran; Penilaian dilakukan dalam berbagai bentuk sesuai dengan prinsip materi yang diberikan; Penilaian diberikan di beberapa tahapan dan dilaksanakan selama proses pembelajaran; Sistem penilaian dilampirkan dalam laporan akhir secara rinci sesuai dengan standar penilaian yang telah ditetapkan.

\section{SIMPULAN DAN SARAN}

\section{Simpulan}

Pembelajaran yang telah dirumuskan berdasarkan standar mutu dinilai cukup baik dalam pelaksanaannya selama masa Pandemi covid-19. Hal ini dapat dilihat berdasarkan kuesioner yang telah disebarkan kepada mahasiswa dengan beberapa pertanyaan yang terdiri dari sembilan indikator kualitas pembelajaran yaitu: 1) kualitas rencana pembelajaran, 2) kualitas kegiatan pembelajaran, 3) kualitas strategi penyampaian, 4) kualitas interaksi antara mahasiswa serta mahasiswa dengan dosen, 5) kualitas interaksi mahasiswa dengan bahan ajar, 6) kualitas sistem umpan balik, 7) kualitas penilaian pembelajaran, 8) kualitas layanan bantuan pembelajaran, serta 9) kualitas kolaborasi. Hasil penelitian menunjukkan bahwa pembelajaran e-learning menurut persepsi mahasiswa berada pada kriteria cukup baik dengan persentase sebesar 50\%, kurang baik $28 \%$, Baik $11 \%$, tidak baik $6 \%$ dan sangat baik 5\%.

\section{Saran}

Agar kegiatan pembelajaran e-learning berjalan lebih efektif dan efisien lagi, sebaiknya mengadakan learning management system secara mandiri agar pembelajaran menjadi lebih maksimal. 


\section{DAFTAR RUJUKAN}

Aqib, M. A. and Khoiriyah, M. (2020) 'Analisis kepuasan mahasiswa terkait kinerja pembelajaran daring oleh dosen via aplikasi Whatsapp Grup', Indonesian Journal of Humanities and Social Sciences, 1(November), pp. 141-153. doi: 10.33367/ijhass.v1i3.1454.

Baety, D. N. and Munandar, D. R. (2021) 'Analisis efektifitas pembelajaran daring Dalam menghadapi wabah pandemi Covid-19', Edukatif: Jurnal Ilmu Pendidikan, 3(3), pp. 880-889. doi: 10.31004/edukatif.v3i3.476.

Baharun, hasan and Zamroni, Z. (2017) Manajemen Mutu Pendidikan. 1st edn, Akademia Pustaka. 1st edn. Edited by A. Muadin. Tulungagung: Akademia Pustaka.

Bora, M. A. (2017) 'Analisa kepuasan penggunaan E-Learning Cloud Sekolah Tinggi Teknik (STT) Ibnu Sina Batam', Jurnal Industri Kreatif(Jik), 1(01), p. 55. doi: 10.36352/jik.v1i01.49.

Hamdani, A. R. and Priatna, A. (2020) 'Efektifitas implementasi pembelajaran daring (full online) dimasa pandemi Covid-19 pada jenjang Sekolah Dasar di Kabupaten Subang', Didaktik: Jurnal Ilmiah PGSD STKIP Subang, VI(01), pp. 1-9. doi: 10.36989/didaktik.v6i1.120.

Handayani, E. F. and Wiyata, M. T. (2020) 'Evaluasi kepuasan pengguna E-Learning pada proses pembelajaran daring Di Institut Manajemen Wiyata Indonesia’, Arika, 14(2), pp. 75-82. doi: 10.30598/arika.2020.14.2.75.

Napitupulu, R. M. (2020) 'Dampak pandemi Covid-19 terhadap kepuasan pembelajaran jarak jauh', Jurnal Inovasi Teknologi Pendidikan, 7(1), pp. 23-33. doi: 10.21831/jitp.v7i1.32771.

Pramuniati, I. et al. (2020) Pengembangan sistem penjaminan mutu dalam implementasi pembelajaran daring di Universitas Negeri Medan. 1st edn. Medan: Universitas Negeri Medan.

Saifuddin, M. F. (2018) 'E-Learning dalam Persepsi Mahasiswa', Jurnal VARIDIKA, 29(2), pp. 102-109. doi: $10.23917 /$ varidika.v29i2.5637.

Sitepu, B. P. and Lestari, I. (2018) 'Pelaksanaan rencana pembelajaran semester dalam proses pembelajaran di Perguruan Tinggi', Perspektif ilmu Pendidikan, 32(1), pp. 41-49. doi: 10.21009/PIP.321.6.

Subhi, I. (2020) 'Urgensi upaya menjaga mutu pembelajaran di tengah pandemi Covid 19', Edification Journal, 3(1), pp. 35-56. doi: 10.37092/ej.v3i1.213.

Zuraini, Z. and Nurhayati, N. (2021) 'Efektifitas pembelajaran E-Learning di era New Normal', Genta Mulia Jurnal Ilmiah pendidikan, 1(01), pp. 130-136. Available at: https://www.ejournal.stkipbbm.ac.id/index.php/ gm/article/view/563 (Accessed: 13 September 2021). 